\title{
Antiangiogenic Effect Of The Chloroform Extract Of Tinospora crispa (L.) Miers Stem In The Chick Embryo Chorioallantoic Membrane (CAM) Induced By bFGF
}

\author{
Asih Triastuti \\ Prodi Farmasi Universitas Islam Indonesia, email:atea_bening@yahoo.com
}

\begin{abstract}
Cancer is one of the most complex disease involving molecular process cause it is hard to be cured. There are many natural compounds which have been used empirically in the society in order to treat cancer. One of them is a kind of herbal medicine called 'Brotowali' (Tinospora crispa (L.) Miers). The objective of this research was to know antiangiogenic effect of the chloroform extract of brotowali stem using CAM method induced by bFGF. In this research, the inhibition test is done by the CAM at 9 day chick embryo divided into seven groups of treatment. Group I is as the paper disc controller, group II as the bFGF controller, group III as bFGF + DMSO $0,8 \%$ solvent controller, group IV, V, VI and VII, as the group that conduct the angiogenesis inhibition test. The last four group were given $10 \mathrm{ng}$ of bFGF each and the chloroform extract of brotowali stem with the doses of $15 \mu \mathrm{g} / \mathrm{ml}, 60$ $\mu \mathrm{g} / \mathrm{ml}, 240 \mu \mathrm{g} / \mathrm{ml}$ and $960 \mu \mathrm{g} / \mathrm{ml}$. After having been incubated for 3 days (egg at 12 day), CAM were carefully observed macroscopically and microscopically. The result showed that the chloroform extract of brotowali stem can inhibit the angiogenesis in CAM induced by bFGF. It show that the angiogenesis inhibition for the dose of the chloroform extract of brotowali stem were successively rise due to the dose increment, with angiogenic potency $31,87 \pm 9,01 \%, 43,12 \pm 8,01 \%, 53,44 \pm 2,70 \%$ and $62,81 \pm 4,74 \%$.
\end{abstract}

Keywords : cancer, angiogenesis, Tinospora crispa (L.) Miers, bFGF, CAM 